\title{
Konsumsi Ikan dan Potensi Anisakiasis: Aspek Komunikasi Kesehatan Masyarakat Suatu Program Pemerintah
}

\author{
Ekarini Daroedono*
}

\begin{abstract}
Communication in the health sector plays an important role in the context of educating people and the society. The emphasis is rely primarily on promoting health so that behavior changes occur. One of the example is a government program "GEMARIKAN" which was designated to increase fish consumption in the community. Unfortunately, the triumph upon this programme is overshadowed by the potential transmission of zoonotic infections of the nematode worm named Anisakis spp. This worm can caused a potentially fatal and deadly disease called anisakiasis. This risk can be reduced by re-conducting numerous education in the community regarding these parasites, their life cycles, its host behaviors and lifestyles that can facilitate transmission such as eating fish in raw conditions and the need of good handling practices of fish to avoid transmission to occur.
\end{abstract}

Keywords: anisakiasis, behavior, promotion, raw fish, zoonosis

Peran komunikasi penting dalam setiap aspek kehidupan, termasuk dalam bidang kesehatan. Salah satu tujuannya adalah mengedukasi pemirsa atau pendengarnya, dalam bidang kesehatan titik beratnya ada pada promosi kesehatan. ${ }^{1}$ Tujuannya agar tercapai perubahan atau perbaikan perilaku pada taraf individual dan masyarakat. Semua aspek kesehatan, dari bidang biomolekuler sampai organ, dari aspek fisiologi sampai patologis, bertumpu pada komunikasi kesehatan guna mengedukasi dan mencerdaskan masyarakat. Komunikasi kesehatan yang baik dan efektif dapat menjembatani gap antara kenyataan dengan yang diharapkan. ${ }^{1,2}$ Salah satunya dalam hal konsumsi protein hewani yang berasal dari laut. $^{3-5}$

Pemangku kepentingan, dalam hal ini pemerintah, berupaya amat keras meningkatkan kuantitas dan kualitas konsumsi melalui berbagai program yaitu nasional, regional maupun lokal., ${ }^{4,6}$ Meski belum maksimal, di masyarakat telah mulai terjadi peningkatan konsumsi ikan terutama produk laut. ${ }^{7,8}$ Namun upaya peningkatan kuantitas konsumsi ikan ini ternyata juga dapat membawa dampak negatif, salah satunya berupa potensi terjadinya zoonosis akibat penyakit yang diderita ikan kemudian bisa menginfeksi manusia yang mengkonsumsinya. ${ }^{9}$ Salah satu zoonosis ikan yang dapat menular kepada manusia adalah anisakiasis, suatu infeksi zoonosis parasitik akibat cacing Anisakis spp. yaitu cacing golongan nematoda yang cukup sering ditemukan pada ikan laut dalam..$^{10-13}$ Prevalensi penyakit ini beragam dengan jenis ikan yang terinfeksi pun bermacam-macam. ${ }^{10,12,13}$ Transmisi ke manusia terjadi saat ikan terinfeksi dimakan mentah atau tidak dimasak hingga matang. ${ }^{12}$ Aspek perilaku terkait kesehatan masyarakat menopang peningkatan kasus anisakiasis; terlebih dengan merebaknya gaya kuliner yaitu daging ikan dikonsumsi secara mentah. ${ }^{10,12,13}$ Makalah ini bertujuan mengulas mengenai aspek kesehatan masyarakat suatu program pemerintah yaitu yang bertajuk "program Gerakan Memasyarakatkan Makan Ikan" (Gemarikan) dan potensinya terhadap kejadian zoonosis anisakiasis.

\footnotetext{
* Penulis untuk korespondensi :

Departemen Kesehatan Masyarakat Fakultas Kedokteran -

Universitas Kristen Indonesia, Jakarta

Email : ekarini09@gmail.com
} 


\section{KONSUMSI GIZI DENGAN PENEKANAN PADA PROTEIN}

Data nasional di bidang gizi masyarakat menunjukkan konsumsi rerata protein harian masyarakat Indonesia tergolong rendah. ${ }^{2}$ Konsumsi daging, unggas dan ikan-ikanan sebagai sumber protein masyarakat Indonesia total sebesar 123 gram per hari, terdiri dari ikan dan kerang sebanyak 78,4 gram, daging dan unggas sebesar 42,8 gram dan jeroan yaitu 2,1 gram. Rerata konsumsi protein yang tertinggi di Asia Tenggara adalah konsumsi oleh masyarakat Singapura yaitu sebesar 626 gram per hari, jumlah ini jauh melampaui konsumsi protein negara-negara anggota ASEAN lain. ${ }^{2}$ Secara lebih spesifik, rerata konsumsi masyarakat Indonesia terhadap protein hewani berupa ikan yaitu ikan laut maupun ikan air tawar juga masih terbilang rendah. Rata-rata tingkat konsumsi ikan di Indonesia baru mencapai 41 kilogram $(\mathrm{kg})$ per kapita per tahun. ${ }^{3,4}$ Meski mengalami kenaikan di bandingkan tahuntahun sebelumnya yaitu dikisaran angka $37-38 \mathrm{~kg}$ per kapita per tahun, tingkat konsumsi ikan di Indonesia masih kalah jauh dibandingkan negara tetangga seperti Malaysia (rerata konsumsi $70 \mathrm{~kg}$ per kapita per tahun) dan Singapura (dengan rerata konsumsi sebesar $80 \mathrm{~kg}$ per kapita per tahun), bahkan jauh di bawah Jepang yang jumlahnya mendekati $100 \mathrm{~kg}$ per kapita per tahun. ${ }^{2,5}$

Kementerian Kelautan dan Perikanan (KKP) bersama Forum Peningkatan Konsumsi Ikan Nasional (Forikan) mendorong masyarakat Indonesia untuk meningkatkan konsumsi ikan melalui program Gerakan Memasyarakatkan Makan Ikan (Gemarikan). ${ }^{6}$ Berdasarkan data KKP tahun 2016, konsumsi nasional ikan masyarakat Indonesia memiliki pola yang unik dengan gambaran sebagai berikut: (1) kelompok ikan Tuna Tongkol Cakalang (TCT) menjadi yang paling banyak dikonsumsi masyarakat Indonesia dengan persentase porsi mencapai $16,45 \%$, (2) kemudian disusul dengan Kelompok Ikan dan Makanan Jadi (KIMJ) seperti bakso, sosis, nugget dan lainnya sebesar 9,02\%, (3) Berturut-turut disusul oleh kelompok-kelompok ikan lele, patin, dan gabus $7,92 \%$, Kembung 6,65\%, Bandeng 5,43\%, Mujair/Nila 5,26\%, Udang dan Cumi $3,87 \%$, Teri 3,36\%, kelompok TCT asin $2 \%$, dan ikan kembung asin $1,36 \%{ }^{7}$ Jenis produk ikan yang paling banyak dikonsumsi masyarakat Indonesia secara umum didominasi oleh produk-produk ikan segar yang mencapai $76 \% .^{6,7}$ tampaknya, diperlukan strategi komunikasi yang lebih efektif agar sosialisasi gerakan masyarakat mengkonsumsi ikan makin dapat diterima di masyarakat. ${ }^{6}$

Data-data saintifik berbasis bukti telah lama digunakan pengambil kebijakan dalam menentukan suatu kebijakan, termasuk preferensi pilihan ikan untuk di konsumsi masyarakat yang menjadi gambaran bagi seluruh pemangku kebijakan/stake holders dalam menentukan arah kebijakan dan keputusan-keputusan turunannya. Keputusan atau kebijakan pemerintah yang tepat dapat makin memfasilitasi peningkatan konsumsi ikan nasional. ${ }^{3}$ Potensi konsumsi ikan juga dapat ditingkatkan melalui upaya penguatan dan modifikasi makanan berbasis ikan dari kelompok olahan produk ikan segar menjadi makanan jadi. ${ }^{8}$

Mengutip data KKP yang lain, pertumbuhan konsumsi ikan di sepanjang tahun 2010-2014, maka terdapat beberapa propinsi dengan pertumbuhan konsumsi terbesar (tercatat pertumbuhan konsumsi ikan regional propinsi tersebut mencapai $>10 \%$ ) antara lain yaitu provinsi DI Yogyakarta sebesar $22,28 \%$, Nusa Tenggara Barat sebesar 14,78\%, Jawa Tengah sebesar 12,31\%, DKI Jakarta sebesar $11,46 \%$, dan Provinsi Jawa Timur sebesar 10,12\%. ${ }^{7}$ Mencermati angka-angka ini juga menarik karena menunjukkan keberhasilan sejumlah propinsi di Indonesia dalam memacu pertumbuhan konsumsi ikan. Namun tampak masih belum meratanya distribusi konsumsi ikan nasional karena dari lima propinsi di Indonesia dengan konsumsi ikan tertinggi sepanjang 2010-2014 maka empat diantaranya terdapat di Pulau Jawa. Padahal seluruh pulau-pulau diwilayah Indonesia memiliki potensi perikanan yang sangat memadai. ${ }^{3,7}$ Sosialiasi, komunikasi dan juga edukasi menjadi faktor kunci guna meningkatkan kesadaran masyarakat dalam mengkonsumsi ikan, didalamnya termasuk upaya menghindari ekses negatif yang mungkin terjadi akibat konsumsi ikan., ${ }^{6-9}$ 11

\section{POTENSI PERIKANAN NASIONAL INDONESIA}

Indonesia mempunyai potensi laut yang teramat besar, termasuk di dalamnya adalah bidang pangan, namun hingga saat ini belum lagi tergarap dengan baik. Dalam konteks pangan tersebut, data 
konsumsi protein ikan per kapita di Indonesia relatif masih tertinggal di banding dengan Negara-negara lain di regional Asia bahkan dunia. ${ }^{12}$ Pemanfaatan protein bersumber laut/ikan menjadi salah satu alternatif ditengah melambungnya harga daging sapi atau ayam, sumber protein hewani non laut. ${ }^{13}$ Potensi laut Indonesia relatif masih kurang dieksplorasi oleh nelayan-nelayan karena peralatan yang masih relatif terbatas dan sederhana. Penguatan kelembagaan nelayan menjadi salah satu cara upaya mendorong eksplorasi hasil laut sehingga dapat mendorong potensi konsumsi ikan oleh masyarakat. ${ }^{14}$ Selain itu, ini juga menjadi momentum bagi peningkatan kapasitas kelembagaan nelayan. ${ }^{15}$ Jelaslah disini, satu kebijakan pemerintah yang tepat bisa menggerakkan banyak aspek kehidupan masyarakat. ${ }^{6}$

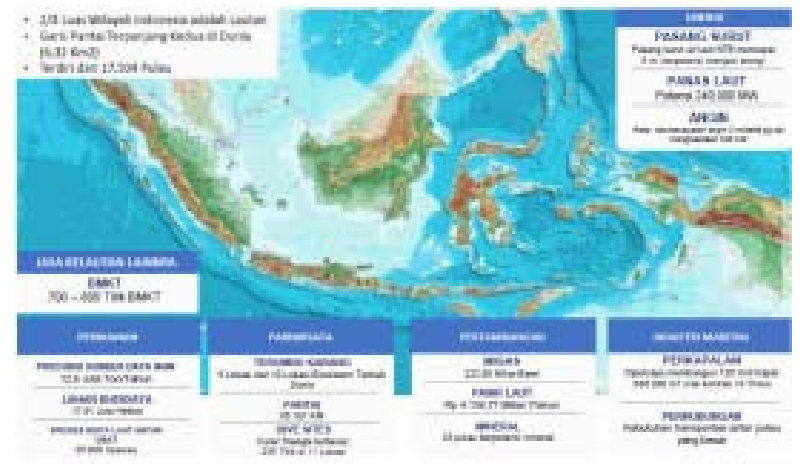

Gambar 1. Peta Potensi ekonomi wilayah laut Republik Indonesia (Kementerian kelautan dan perikananan (2018) dengan modifikasi)

Meskipun tingkat konsumsi ikan di Indonesia setiap tahunnya terjadi peningkatan, namun dapat dikatakan masih rendah. ${ }^{5,14}$ Rendah atau tingginya tingkat konsumsi ikan di suatu negara ditentukan oleh jumlah konsumsi ikan per kapita pertahun dan dibandingkan dengan angka persediaan ikan. ${ }^{5}$ Pada 2018, ditargetkan konsumsi ikan lebih meningkat mencapai target $50,65 \mathrm{~kg} / \mathrm{kapita}$. Masih rendahnya tingkat konsumsi ikan di Indonesia menunjukan perilaku masih rendahnya budaya makan ikan di masyarakat. ${ }^{15}$ Kementerian Kelautan dan Perikanan (KKP) sebagai pemangku kebijakan utama mengenai perikanan di Indonesia telah menetapkan beberapa strategi kebijakan dengan tujuan meningkatkan kemandirian dalam mengelola sumber daya kelautan dan perikanan secara berkelanjutan. ${ }^{6,14}$ Komunikasi menjadi penting dalam konteks sosialisasi program agar membumi ke seluruh lapisan masyarakat. Seluruh kebijakan serta upaya strategis yang dilakukan bertujuan untuk meningkatkan kesejahteraan masyarakat terutama masyarakat di daerah pesisir dan keberlanjutan sumber daya kelautan dan perikanan untuk generasi mendatang, salah satunya melalui penetapan dan peringatan Hari Ikan Nasional. ${ }^{8}$

\section{HARI IKAN NASIONAL DAN PROGRAM "GERAKAN MEMASYARAKATKAN MAKAN IKAN” (GEMARIKAN)}

Peringatan Hari Ikan Nasional merupakan momentum bagi bangsa Indonesia untuk mengingatkan sekaligus membangun kesadaran nasional tentang peran penting sektor kelautan dan perikanan dalam pembangunan Indonesia secara menyeluruh baik aspek ekonomi, politik, sosial, budaya, pangan, pelestarian lingkungan serta sumber daya manusia Indonesia. ${ }^{4,8,13}$

Dengan mempertimbangkan pentingnya peran perikanan bagi pembangunan sumberdaya manusia dan ekonomi Indonesia yang menyeluruh serta mewujudkan kedaulatan pangan, maka para pemangku kepentingan di sektor kelautan dan perikanan yang tergabung dalam organisasi Masyarakat Perikanan Nusantara (MPN) serta Kementerian/Lembaga terkait mengusulkan dan menginisiasi Hari Ikan Nasional. ${ }^{6,14}$ Hari Ikan Nasional adalah suatu hari yang diperingati secara nasional yaitu pada setiap tanggal 21 November dalam rangka menggugah kesadaran dan mengingatkan masyarakat mengenai peran penting ikan sebagai sumber daya alam bernilai strategis dan bertujuan untuk meningkatkan perekonomian dan kualitas sumber daya manusia Indonesia yang pada akhirnya diharapkan akan menjadi bagian internalisasi dari budaya bangsa Indonesia. ${ }^{8}$

Kajian akademis atas program ini telah dilakukan, kebanyakan masih bersifat sporadis lokal. Misalnya seperti yang dilakukan oleh oleh Rudianto ${ }^{16}$ pada tahun 2017 yang meneliti dampak pelaksanaan Program Gerakan Memasyarakatkan Makan Ikan (Gemarikan) Terhadap peningkatan konsumsi ikan rumah tangga di Kecamatan Lowokwaru di Kota Malang. Hasil kajiannya menunjukkan meskipun ditemukan kecenderungan meningkatnya jumlah 
konsumsi ikan akibat sosialisasi gerakan tersebut, namun tetap saja masih perlu lebih ditingkatkan lagi implementasi pelaksanaan program agar dampak positif yang diharapkan dapat tercapai dan merata di seluruh Kota Malang.

Penelitian seperti yang dilakukan oleh Rudianto ${ }^{16}$ memang bermanfaat, meski terdapat juga kelemahan, karena cakupannya yang terbatas pada wialayah tertentu atau tidak mewakili keseluruhan daerah tempat program dilaksanakan yaitu wilayah negara kesatuan Republik Indonesia. Hendaknya, penelitian epidemiologis komunal sejenis memperhatikan hal-hal sebagai berikut seperti pelaksanaan penelitian disesuaikan dengan kondisi nyata/real time wilayah dan diperlukan penelitian lanjutan yang berkaitan dengan pola konsumsi masyarakat, selain itu perbandingan konsusmsi antar wilayah juga diperlukan guna mengetahui kebutuhan daerah secara lebih spesifik. Sedangkan, saran praktis bagi penelitian-penelitian epidemiologis komunal sejenis adalah perlunya dilakukan evaluasi setelah program diimpelementasikan, dan perlunya memaksimalkan setiap usaha/ kegiatan dan membuat peta pola konsumsi lokal yang akan bermanfaat bagi pemangku kebijakan. ${ }^{3}$ Dalam hal ini, peran komunikasi kesehatan menjadi vital. ${ }^{6}$

\section{Tantangan Kesehatan Dalam Upaya peningkatan Konsumsi Ikan Masyarakat: Anisakiasis}

Dalam upaya meningkatkan konsumsi ikan di masyarakat, pemerintah telah banyak melakukan kegiatan dengan semua pemangku kepentingan guna mempercepat tercapainya peningkatan konsumsi. ${ }^{4}$

Hanya saja, terdapat kendala dalam upaya ini, salah satunya adalah dari potensi terjadinya zoonosis, yaitu transmisi infeksi dari hewan ke manusia. ${ }^{10-13}$ Salah satu jenis zoonosis yang sering ditemukan adalah anisakiasis, suatu infeksi cacing golongan nematoda yang disebabkan oleh cacing Anisakis spp..$^{10-12}$

Anisakiasis atau dalam bahasa Inggris awam sering disebut sebagai "herringworm" adalah infeksi parasitik yang disebabkan cacing nematoda Anisakis spp. complex. Cacing ini menginfeksi ikan laut yang memiliki karakteristik karnivora atau predator. ${ }^{13}$ Ikan dan invertebrata akuatik seperti gurita, cumi-cumi atau sotong mendapat infeksi saat larva stadium bebas 'termakan' bersama zoo-plankton yang ada di laut. Ikan laut merupakan bentuk hospes perantara cacing Anisakis, sedang hospes definitif nya adalah anjing laut dan ikan-ikan laut lain yang berukuran lebih besar dan memakan ikan laut yang berukuran lebih kecil. ${ }^{10}$

Pada hospes perantara tersebut, cacing ini berada pada larva stadia III (L3). Anisakis spp umumnya hidup dan ditemukan pada dinding usus, hati dan otot ikan sehingga pada ikan sendiri dapat langsung menimbulkan efek patologis dan jika ikan yang sakit termakan oleh manusia bisa juga menimbulkan masalah kesehatan pada manusia (zoonosis). ${ }^{13}$ Manusia berperan sebagai hospes aksidental, dan didalam tubuh manusia L3 yang tertelan tidak akan dapat berkembang menjadi stadium yang lebih matang (stadium cacing dewasa). ${ }^{11}$

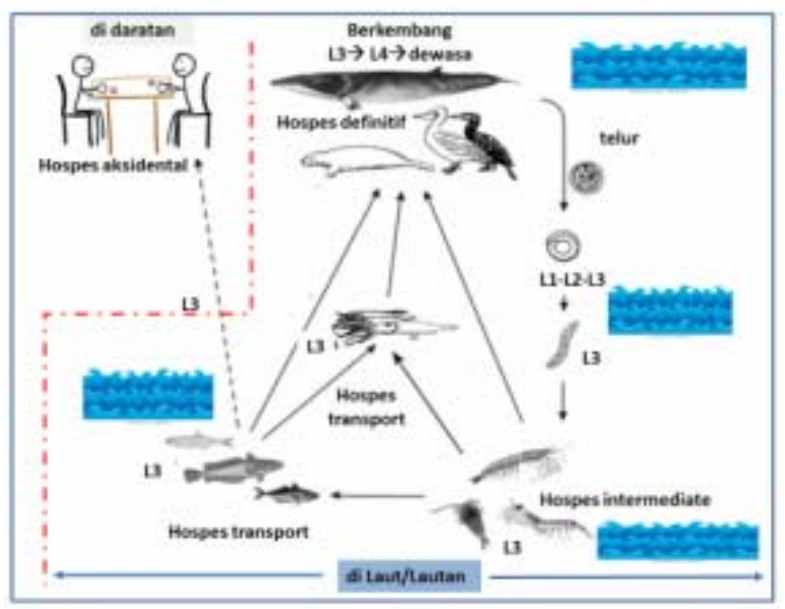

Gambar2. Siklus hidup Anisakis spp yang melibatkan beberapa spesies hospes dalam tahapan perkembangannya dari stadium telur, stadium larva(L) hingga menjadi stadium dewasa.

Gejala klinis pada manusia beragam dari reaksi alergi dengan spektrum ringan sampai berat dan bahkan pernah dilaporkan sampai menyebabkan gangguan mekanis pada saluran cerna. ${ }^{12}$ Dalam tubuh manusia, L3 cacing ini tidak akan pernah dapat berkembang menjadi dewasa, sehingga manusia lebih sebagai hospes aksidental. ${ }^{10-12}$ Masalah yang ditimbulkan lebih terkait sebagai respons alergi akibat allergen yang dikandung L3 atau bisa juga sebagai 
respons patologis tubuh terhadap keberadaan L3 dalam bentuk reaksi jaringan. ${ }^{17}$

Variasi spesies ikan laut yang terinfeksi oleh cacing golongan ini amat lebar karena tipikal tropisme atau pola spesifisitas hospes nya yang minim. Dengan kata lain, virulensi cacing ini tidak terbatas karena memiliki kemampuan menginfeksi banyak jenis ikan dan tidak terbatas hanya pada spesies ikan tertentu. Di Indonesia, ikan laut yang banyak diminati masyarakat seperti ikan tongkol (Auxis rochei dan Euthynnus affinis), ikan cakalang (Katsuwonus pelamis), ikan kerapu (Epinephelus spp), ikan layur (Trichiurus spp), ikan bentong (Selar crumenophthalmus), ikan kakap (Gymnocranius microdon), ikan laying (Decapterus russeli), ikan bawal (Pampus argenteus) dan masih banyak lagi jenis yang lain pernah dilaporkan dari banyak tempat di Indonesia. ${ }^{12}$ Sayangnya, salah satu kelemahan hasil-hasil penelitian dari Indonesia mengenai anisakiasis pada ikan adalah cakupannya yang terbatas dan sporadis. ${ }^{18}$ Sedangkan dari paper ilmiah luar negeri pernah dilaporkan ikan-ikan laut seperti herring (Clupea harengus), mackerel (Scomber scombrus L) Atlantic salmon (Salmo satar $L$ ).; cod (Gadus morhua L), whiting (Merlangius merlangus) blue whiting (Micromesistius poutassou (Risso)); Atlantic salmon (Salmo salar) dan masih banyak lagi spesies dalam kelompok teleosts dan cephalopod yang pernah dilaporkan dari berbagai belahan dunia terinfeksi oleh cacing nematoda ini. ${ }^{10,13}$

Deretan ikan tersebut memiliki nilai ekonomis tinggi karena menjadi primadona komoditas laut di masyarakat. ${ }^{14}$ Selain itu, eksotisme dan kualitas ikan-ikan tersebut juga mendorong menjadikannya sebagai komoditas ekspor dari negara-negara produsen/pemasok ke negara-negara lain. Strategi komunikasi pemerintah, dalam hal ini kementerian perikanan juga berperan dalam cakupan sebaran produk perikanan nasional menjadi global ${ }^{4,6}$ Praktek perdagangan bebas seperti ini kemungkinan besar juga memfasilitasi distribusi infeksi sampai ke tempat-tempat dengan posisi geografis yang letaknya jauh dari lokasi awal habitat alamiahnya. ${ }^{10,19}$ Selain itu, aspek perilaku masyarakat sebagai konsumen ikan laut juga mempengaruhi keberhasilan transmisi anisakiasis. ${ }^{5,13,19}$

\section{Aspek perilaku masyarakat yang Memfasilitasi Transmisi Anisakiasis: Kuliner}

Cara infeksi atau transmisi anisakiasis dari ikan ke manusia adalah melalui jalur per oral, yaitu manusia secara tidak sengaja mengkonsumsi atau tertelan daging/organ ikan yang mengandung larva L3. ${ }^{10-12,19}$ Dengan bantuan mekanis dari proses mengunyah dan secara enzimatik di lambung, maka larva L3 dapat dibebaskan dari otot atau organ dalam ikan yang dikonsumsi. ${ }^{12,20}$ Pola penyajian dalam bentuk fillet juga meningkatkan resiko, karena dengan memotong daging ikan secara fillet berarti bisa membebaskan larva dari reaksi jaringan yang mungkin sudah terbentuk sebagai respons alamiah tubuh ikan terhadap adanya benda asing. ${ }^{13,20}$

Secara teoritis, parasit akan dapat dimatikan dengan perlakuan yang sesuai. Cara memasak masyarakat Indonesia pada umumnya, apapun sukunya, sebenarnya telah memenuhi syarat yang memadai untuk mematikan agen-agen parasitik yang kemungkinan terdapat dalam makanan (food borneparasite) karena biasanya selalu dimasak hingga matang dalam waktu yang cukup memadai.

Aspek perilaku masyarakat terkait transmisi secara lebih spesifik adalah dengan gaya kuliner mengkonsumsi daging ikan secara mentah atau dimasak tidak matang. ${ }^{12,19}$ Tren kuliner restoran Jepang dan Korea Selatan di kota-kota besar Indonesia yang sedang booming dengan isu eksotisme makanan alamiah ternyata juga meningkatkan resiko, jika ikan yang dikonsumsi ternyata mengandung larva L3 Anisakis spp. ${ }^{9}$

Di negara asal gaya kuliner tersebut, prevalensi anisakiasis pada manusia ternyata lebih tinggi dibanding negara-negara yang tidak punya kebiasaan mengkonsumsi ikan mentah. ${ }^{10}$ Salah satu panel atau kelompok kerja dalam The European Food Safety Authority (EFSA) yang berfokus pada bahaya biologis/Biological Hazards (BIOHAZ) mengestimasi sejumlah 20,000 kasus anisakiasis terkonfirmasi secara global telah terjadi hingga sebelum tahun 2010 , dengan $>90 \%$ nya berasal dari Jepang. ${ }^{13}$ Di negara-negara benua Eropa, Spanyol menjadi negara Eropa yang paling banyak terdampak anisakiasis, terutama akibat kebiasaan mengkonsumsi makanan asin tradisional yang disebut "anchovies in vinegar". Meski demikian, angka kejadian pasti secara global tetap belum 
diketahui karena data epidemiologis yang langka dan tidak seragam. Menjadi amat penting untuk mengetahui insidens anisakiasis pada populasi sehingga dapat diperkirakan besarnya masalah untuk mengambil langkah-langkah yang diperlukan untuk mengurangi insidens..$^{10}$

Beberapa jenis makanan berbahan dasar ikan laut yang lazim dikonsumsi mentah dan saat ini popular di kalangan masyarakat misalnya adalah sushi dan sashimi (Jepang), Gravlaks (Negara-negar Skandinavia), boquerones en vinagre (Spanyol) Umai dan Esqueixada (Catalan-Spanyol), lomi-lomi salmon (Hawai, Amerika Serikat), Carpacio dan Crudo (Italia), Ceviche dan Tiradito (Peru), E'ia Ota (Tahiti), Gohu Ikan (Maluku-Indonesia), Hinava (Malaysia), Hoe (Korea), kelaguen (Kep. Mariana), Kilawin(Filipina), Koi Pla (Thailand), Kokoda (Fiji), Kuai (China), Lakerda (Turki), Lap pa (Laos), Larb pla (Thailand), 'Ota 'ika (Tonga), Soused herring/ maatjes /matjes (Belanda), Stroganina (Siberia), Tuna tartare (Amerika serikat), Umai dan Yusheng (Malaysia).

Ikan dalam daftar yang disebutkan sebelumnya merupakan jenis ikan laut mentah (mungkin saja terlebih dahulu direndam dalam larutan tertentu sebelum dikonsumsi, misalnya dalam cuka) namun pasti bukan ikan yang telah diolah baik secara fermentasi, diasap atau diawetkan.

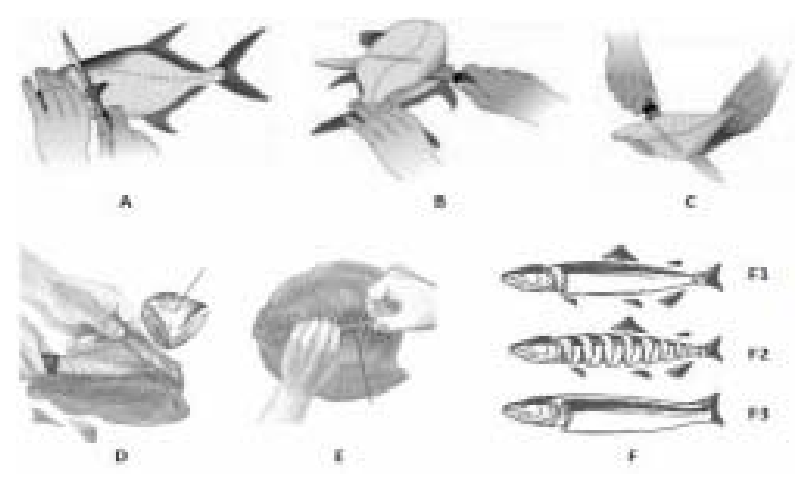

Gambar 3. Cara memotong ikan menjadi irisan tipis/ fillet. A. pisahkan bagian kepala, B. mulai irisan dari bagian ekor, C. Lepaskan seluruh bagian, D. Lepaskan duri dengan pisau, E. angkat duri secara utuh, perlahan agar tidak terputus, F. Jenis-jenis irisan: F1. Irisan utuh
Dalam konteks makanan Jepang, sering terdapat salah persepsi antara "Sushi" dan "Sashimi". Meski tidak bermaksud untuk mengulas aspek kuliner secara teknis, namun dalam konteks tulisan ini, daging ikan yang digunakan hampir selalu disajikan dalam keadaan mentah dan segar, diiris tipis atau dipotong fillet dan dikonsumsi langsung tanpa dimasak hanya dengan saus kedelai atau kecap asin. Penikmat model kuliner ini (dimakan mentah) mengedepankan isu mengenai freshness/kesegaran dan natural/alamiah serta sensasi menikmati makan yang berbeda dibanding dengan makanan lain yang disiapkan dengan cara konvensional seperti dimasak. ${ }^{19}$

Ikan yang diiris tipis/fillet sebenarnya justru meningkatkan kemungkinan larva yang tadinya terkurung jauh di dalam jaringan dan mungkin telah terlokalisir oleh sebentuk reaksi peradangan lokal jaringan (biasanya jaringan fibrosa) kemudian justru menjadi terbuka akibat insisi/penyayatan. ${ }^{20}$ Jika irisan daging ikan yang tipis/fillet ini kemudian langsung dimakan secara mentah, maka L3 tersebut berpotensi dibebaskan dari jaringan yang mengikatnya, baik secara mekanis oleh gerakan mengunyah dan secara kimiawi di lambung. ${ }^{17,20}$ Setelah melalui lambung, L3 yang sudah dibebaskan mulai menimbulkan masalah di usus halus. ${ }^{17,19,20}$

Berikut akan dibahas mengenai aspek kesehatan masyarakat program pemerintah Gemarikan dalam konteks transmisi zoonosis Anisakis spp.

\section{Aspek kesehatan Masyarakat Suatu program pemerintah: Gerakan Memasyarakatkan Makan Ikan (Gemarikan)}

Indonesia sebagai negara maritim terbesar di dunia sebenarnya mempunyai sumber daya ikan yang melimpah namun sayangnya ikan belum dimanfaatkan sebagai sumber utama ketahanan pangan dan gizi nasional secara optimal. Pada tahun 2004, tingkat konsumsi ikan nasional masih sangat rendah yaitu sebesar $24.67 \mathrm{~kg} / \mathrm{kapita} / \mathrm{tahun}$; angka ini masih jauh dibawah Pola Pangan Harapan 31,4 $\mathrm{kg} / \mathrm{kapita}$. Hal ini yang mendasari dicanangkannya program Gerakan Memasyarakatkan Makan Ikan (GEMARIKAN) yang diresmikan oleh presiden RI waktu itu, Ibu Megawati Soekarno Putri pada tanggal 
4 April 2004.

Peningkatan konsumsi ikan di kalangan masyarakat, memberikan dampak pada penyerapan produk-produk perikanan, baik ikan segar maupun produk olahan atau produk turunannya, sehingga pada akhirnya meningkatkan dan menggerakkan industri perikanan nasional.

Secara kebijakan, analisis terhadap program pemerintah GEMARIKAN yang sudah berjalan lebih kurang 14 tahun ini (2004 sampai 2018) masih terus berlangsung. Berikut akan disampaikan kajian atau analisis mengenai hal tersebut dengan menggunakan data yang dikeluarkan oleh Biro Pusat Statistik.

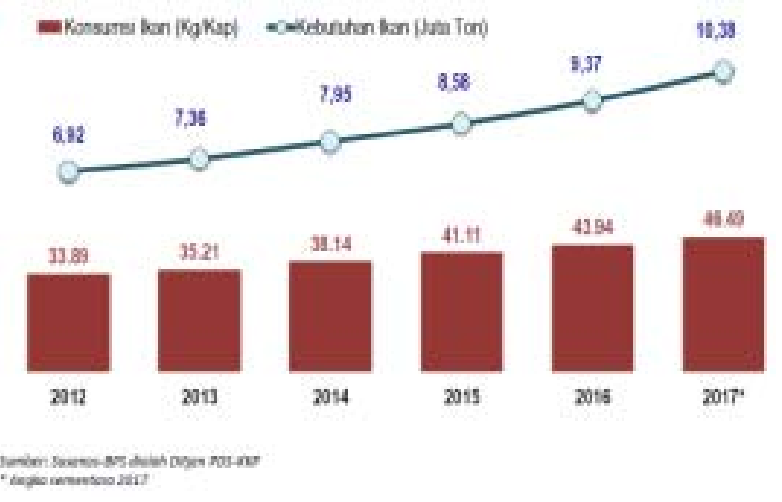

Gambar4. Tren konsumsi dan permintaan/kebutuhan ikan nasional tahun 2012 sampai 2017

Jika pada tahun 2004, tingkat konsumsi ikan nasional masih sangat rendah yaitu sebesar 24.67 $\mathrm{kg} / \mathrm{kapita} /$ tahun, maka gambar 4 menunjukkan pola kecenderungan konsumi yang meningkat dalam lima tahun terakhir; bahkan pada 2017, terjadi peningkatan konsumsi per kapita hampir dua kali lipat dibanding saat awal dicanangkan. ${ }^{7}$

Melimpahnya kekayaan hayati sumberdaya laut negara kesatuan Republik Indonesia masih belum diolah secara optimal. ${ }^{4,14}$ Secara geografis, $>60 \%$ wilayah negara kesatuan Republik Indonesia terdiri dari lautan; di dalamnya tersimpan potensi kekayaan sumberdaya laut Indonesia. Secara nasional, potensi perikanan hasil tangkapan saja mencapai 6,26 juta ton/tahun dengan keragaman jenis ikan namun dari jumlah itu belum seluruh potensinya dimanfaatkan dengan baik. Misalnya, sepanjang tahun 2005 yang lalu ( $>10$ tahun yang lalu) jumlah total keseluruhan produksi perikanan nasional mencapai jumlah 4,71 juta ton; sejumlah $3 / 4$ nya atau setara dengan 3,5 juta ton justru berasal dari hasil tangkapan laut, baik penangkapan secara tradisional maupun modern. Sayangnya, tingkat pemanfaatannya, terutama untuk kelompok ikan-ikan non ekonomis, masih belum optimal. Salah satu sebabnya adalah pemanfaatannya yang masih terbatas dalam bentuk olahan tradisional dan konsumsi segar. Akibatnya ikan-ikan jenis ini tidak ditangani dengan baik di kapal, sehingga ikanikan yang didaratkan bermutu rendah ( hanya mencakup 20-30\% dari total keseluruhan tangkapan). Hal itu kemudian berdampak pada tingginya tingkat kehilangan atau kerusakan (akibat berbagai sebab). ${ }^{7}$

Lebih jauh lagi, ekspor produk dan hasil perikanan laut Indonesia hingga saat ini masih terus didominasi oleh ikan-ikan yang dijual dalam bentuk gelondongan dan belum diolah secara modern. ${ }^{14,15}$ Sebagai konsekuensinya, usaha pengolahan produk hasil perikanan di Indonesia belum berkembang akibat pola-pola produksi yang semi modern; sehingga posisi tawar industri perikanan lokal dalam perdagangan dunia belum cukup kuat dan belum bisa bersaing dengan industri perikanan modern negaranegara produsen.

Secara garis besar, dari keseluruhan total produksi tangkapan laut nasional maka rata-rata sebesar 57,05\% dimanfaatkan dalam bentuk produk segar, lalu sebanyak 30,19\% berupa bentuk olahan tradisional dan sebesar 10,90\% dalam bentuk olahan modern dan olahan lainnya $1,86 \%$. Sedangkan data ekspor perikanan laut Indonesia tahun 2005 mencapai 857.782 ton dan $80 \%$ diantaranya didominasi produk olahan modern sedangkan produk olahan tradisional hanya sekitar $14 \%$ saja. $^{7}$

Dalam konteks hasil laut Indonesia, rentang cakupan potensinya dimulai dari usaha penangkapan, upaya budidaya, hasil tangkapan utama dan penyerta serta sisa dari olahan industri perikanan. Sebenarnya, potensi meningkatkan nilai tambah maupun nilai jual komoditas ikan-ikan non ekonomis masih dapat diupayakan melalui teknologi dan rekayasa pengembangan produk-produk hasil perikanan laut; prinsipnya bukan sesuatu yang dilakukan hanya secara sambil lalu atau dengan teknologi sederhana seperti diasinkan atau diasap. ${ }^{18}$ Hanya saja, hal ini membutuhkan peran serta dan campur tangan dari seluruh pemangku kepentingan, agar penerapan 
teknologi tepat guna juga menyentuh inti permasalahan, yaitu diversifikasi dan optimalisasi produk olahan hasil laut. ${ }^{8}$

Secara garis besar, terdapat beberapa poin penting mengenai pengolahan dan pemasaran hasil perikanan nasional, yang amat perlu untuk ditata dalam upaya meningkatkan konsumsi produk hasil laut Indonesia, diantaranya adalah:

1. Hingga saat ini, hasil tangkap lokal masih sulit bersaing dengan kompetitor luar untuk menembus pasar global salah satunya karena belum adanya penyeragaman/standarisasi dalam model/sistem penjaminan mutu dan keamanan produk hasil perikanan laut Indonesia,

2. Tingkat/laju terjadinya kehilangan produk/hasil laut nasional (akibat berbagai sebab diantaranya yang paling dominan adalah pencurian oleh kapalkapal ikan asing modern) masih amat tinggi (bisa mencapai $27,8 \%$ dari keseluruhan hasil tangkapan dalam setahun

3. Intensitas (baik dalam hal kualitas maupun kuantitas) promosi produk hasil laut lokal Indonesia di masyarakat sendiri masih rendah (baik dari aspek iklan, edukasi maupun gambaran produk lain) dan juga partisipasi dari seluruh pemangku kepentingan terkait yang masih jauh dari optimal,

4. Masih terus adanya keterbatasan sarana dan prasarana terkait penanganan ikan hasil tangkapan sehingga memperpanjang masa produksi dan memperlama waktu dari sejak ikan ditangkap hingga sampai ke tangan konsumen,

5. Minimnya pasokan bahan baku industri yang bermutu baik karena alat tangkap yang kebanyakan sudah ketinggalan jaman, bahkan masih tradisional namun masih tetap digunakan, sehingga seringkali justru menurunkan mutu ikan hasil tangkapan

6. Standarisasi bahan baku yang belum ada atau belum diterapkan,

7. Secara sporadis masih ditemukannya penggunaan bahan-bahan kimia berbahaya,

8. Upaya diversifikasi terhadap jenis ragam produk serta upaya pengembangan produk belum maksimal kemungkinan karena belum adanya sinergi antara akademisi, industri dan masyarakat sebagai konsumen,

9. Ikan dan hasil laut dalam konteks akhir sebagai produk pangan ternyata masih rendah konsumsi per kapita nya secara nasional baik karena alasan harga maupun distribusi yang belum merata, dan

10. Masih terbatasnya peran teknologi informasi dalam proses produksi; didalamnya termasuk masih belum sinerginya peran lembaga tinggi pendidikan dan industri dalam menopang seluruh rantai produksi perikanan nasional dari mulai hulu sampai hilir.

Banyak langkah-langkah strategis relevan yang telah dan akan diambil oleh pemerintah, dimana intinya adalah berupa upaya-upaya meningkatkan konsumsi ikan produk laut Indonesia yang aman dan higienis serta ditopang oleh penyediaan teknologi pengolahan pangan terkait produk-produk perikanan laut guna meningkatkan efisiensi produksi di sektor industri. $^{7}$

Dari segi konsumsi, besarnya potensi tersebut tidak diikuti dengan tingkat konsumsi ikan dalam negeri yang tinggi pula. Menurut Direktorat Pemasaran Dalam Negeri/PDN (2011), penyediaan ikan untuk konsumsi di Indonesia pada tahun 2009 adalah 30,95 kg/kapita dengan tingkat konsumsi ikan $29.08 \mathrm{~kg} / \mathrm{kapita}$. Tingkat konsumsi ini masih di bawah tingkat konsumsi ikan di beberapa negara, di antaranya Jepang (110 kg/kapita), Korea Selatan (85 $\mathrm{kg} / \mathrm{kapita}$ ), Amerika Serikat ( $80 \mathrm{~kg} / \mathrm{kapita})$, Singapura (80 kg/kapita), Hongkong ( $85 \mathrm{~kg} / \mathrm{kapita})$, Malaysia (45 kg/kapita), dan Thailand (35 kg/kapita). Salah satu contoh kota di Indonesia, yaitu Kota Depok sebagai salah satu kota penyangga ibukota Jakarta termasuk dalam kategori kota dengan tingkat konsumsi ikan yang sangat rendah, yakni $13,18 \mathrm{~kg}$ per kapita pada tahun 2008. Padahal, akses dari kota Depok ke ibukota Indonesia yaitu Jakarta dihubungkan oleh jalur transportasi yang baik dengan jarak yang relatif dekat sehingga secara teoritis distribusi dan harga ikan seharusnya tidak boleh jauh berbeda dengan ibukota Jakarta.

Fakta diatas menunjukkan bahwa, konsumsi tidak ditentukan hanya oleh satu faktor, melainkan beberapa faktor yang saling terkait. Dalam konteks masih rendahnya tingkat konsumsi ikan per kapita 
masyarakat Indonesia secara umum disebabkan oleh dua hal yang intinya terkait dengan kelemahan pada sisi penyediaan (supply) dan tingkat permintaan (demand) ${ }^{4,16}$

Beberapa kelemahan pada sisi penyediaan yang menyebabkan masih rendahnya konsumsi ikan di kalangan masyarakat Indonesia yaitu karena (1) keterbatasan distribusi dan pasokan ikan yang berkualitas, (2) keterbatasan sarana prasarana pendukung penjualan yang representatif, (3) keterbatasan mata rantai pasokan dan distribusi ikan yang baik, higienis dan mampu menjangkau seluruh penjuru daerah dan (4) belum tersedianya produkproduk makanan substitusi ikan.

Namun akan tetapi sebaliknya, pada sisi permintaan akan pemenuhan kebutuhan ikan laut di masyarakat, terdapat beberapa hambatan dalam pembentukan atau upaya merangsang tumbuhnya budaya makan ikan di kalangan masyarakat Indonesia di antaranya adalah sebagai berikut (1) masih minim dan tidak menentunya stabilitas ketersediaan ikan laut segar berkualitas baik di pasaran lokal, (2) masih adanya ditemukan kepercayaan, perilaku dan atau budaya dikalangan komunitas masyarakat tertentu yang menganggap tabu untuk makan ikan tertentu, (3) masih rendahnya taraf pengetahuan gizi terutama dalam konteks protein nabati hasil laut di kalangan ibu rumah tangga/ perempuan (terutama di pedesaan), (4) di sektor pasar, dari segi harga maka komoditas ikan dan produk olahannya relatif lebih mahal dibanding jenis makanan yang lain, (5) rendahnya kemampuan finansial yang membatasi daya beli masyarakat, (5) rendahnya ragam jenis ikan dan produk diversifikasi olahan hasil perikanan, (6) keterbatasan dalam penguasaan teknologi pengolah pangan yang masih minim, (7) dalam kebiasaan/budaya tertentu, masih terdapat masalah dalam konteks sudut pandang mengenai prestise dan preferensi yang beranggapan bahwa produk ikan masih tetap merupakan bahan pangan inferior (dibandingkan daging hewani non ikan), dan (7) fobia atau ketakutan akan potensi kontaminasi ikan laut oleh logam-logam berat yang berasal dari perairan yang tercemar.

Jika dirunut dari data sporadis mengenai anisakiasis di Indonesia, prevalensi nya yang beragam di hampir seluruh wilayah pemasaran ikan laut di Indonesia maka pendekatan pencegahan transmisi yang perlu dan harus dilakukan oleh seluruh pemangku kepentingan adalah dengan (1) menegakkan pola penanganan ikan terpadu multidisiplin, (2) mengembangkan sentra-sentra pengolahan di daerah serta yang juga mendesak dilakukan adalah (3)

System surveillance aktif terhadap ikan-ikan yang baru saja didaratkan sebelum dipasarkan ke konsumen sehingga dengan demikian meminimalisir potensi kontak masyarakat sebagai konsumen dengan ikan yang terinfeksi. ${ }^{12,13}$

\section{SIMPULAN}

Telah dibahas mengenai bagaimana suatu kebijakan pemerintah mengenai makan ikan dan upaya komunikasi dan sosialisasinya dalam kaitan dampaknya dengan pola konsumsi ikan di masyarakat dan potensi kejadian anisakiasis, suatu zoonosis dari ikan laut yang banyak dikonsumsi manusia serta bagaimana dampak aspek kesehatan masyarakat suatu program pemerintah dalam upaya meningkatkan tingkat konsumsi ikan di masyarakat melalui program GEMARIKAN. Program ini dapat meningkatkan taraf konsumsi, meski belum merata. Perlu dilakukan kajian lebih mendalam atas analisis kebijakan program GEMARIKAN dalam lingkup yang lebih luas, misalnya dalam kaitannya dengan kebijakan-kebijakan terkait dibidang perdagangan dan atau perindustrian, sehingga didapat gambaran yang lebih holistik atas upaya peningkatan konsumsi makan ikan di masyarakat dengan potensi kejadian zoonosis di masyarakat.

\section{DAFTAR PUSTAKA}

1. Nkanunye CC, Obiechina GO. Health Communication Strategies as Gateway to Effective Health Promotion and Well-being. J Med ResHealth Educ 2017, Vol.1 No.3: 13

2. Capparo C, Ott L, Sethuraman. Overview of the Nutrition Situation in Seven Countries in Southeast Asia. Washington, DC: FHI 360/FANTA. 2014

3. Ditjen Pengolahan \& Pemasaran Hasil Perikanan Departemen Kelautan dan Perikanan_Masalah dan Kebijakan Peningkatan produk perikanan untuk pemenuhan gizi masyarakat 
4. Kementerian PPN / Bappenas Direktorat Kelautan dan Perikanan. Kajian strategi pengelolaan perikanan berkelanjutan. 2014. Diunduh dari https://www.bappenas.go.id/files/ $\begin{array}{lllllllllllllll}7 & 6 & 1 & 4 & / & 4 & 4 & 0 & 1 & / & 4 & 2 & 0 & 6 & /\end{array}$ Strategi Pengelolaan_Perikanan_Berkelanjutan.pdf

5. Needham, S., Funge-Smith, S. J. The consumption of fish and fish products in the AsiaPacific region based on household surveys. FAO Regional Office for Asia and the Pacific, Bangkok, Thailand . RAP Publication 2015/12. $87 \mathrm{pp}$

6. Keivin. Strategi komunikasi dinas kelautan dan perikanan dalam mensosialisasikan gerakan memasyarakatkan makan ikan di kota Samarinda. eJournal lmu Komunikasi. 2017; 5(1): 248-59

7. Kementerian kelautan dan perikananan. Produktivitas Perikanan Indonesia. http:// kkp.go.id/wp-content/uploads/2018/01/KKPDirjen-PDSPKP-FMB-Kominfo-19-Januari2018.pdf. Diunduh 27 Agustus 2018

8. Kementerian kelautan dan perikananan. Peringatan Hari Ikan Nasional (HARKANNAS) ke-2 "Kedaulatan Pengelolaan Sumberdaya Kelautan dan Perikanan Secara Berkelanjutan untuk Kesejahteraan dan Kecerdasan Masyarakat".2015. Diunduh dari http://kkp.go.id/ an-component/media/upload-gambar pendukung/ $\begin{array}{lllllllll}\mathrm{d} & \mathrm{j} & \mathrm{p} & \mathrm{d} & \mathrm{s} & \mathrm{p} & \mathrm{k} & \mathrm{p} & /\end{array}$ Buku\%20Panduan_HARKANNAS_04112015.pdf

9. Rinanda T. Aquatic animals and their threats to public health at human-animal-ecosystem interface: a review. AACL Bioflux, 2015. 8 (5): 784-9.

10.Bao M, Pierce GJ, Pascual S, González-Muñoz M, Mattiucci S, Mladineo I, et al. Assessing the risk of an emerging zoonosis of worldwide concern: anisakiasis. Scientific Reports. 2017; 7:43699. DOI: 10.1038/srep43699. https:// www.nature.com/articles/srep43699

11. Buchmann K, Mehrdana F. Effects of anisakid nematodes Anisakis simplex (s.1.), Pseudoterranova decipiens (s.1.) and Contracaecum osculatum (s.1.) on fish and consumer health. Foos and Waterborne Parasitology. 2016. 4: 13-22
12. Adawiyah R, maryanti E, Siagian FE. Anisakis sp. Dan alergi yang ditimbulkannya. JIK. 2014; 8(1):38-45

13.EFSA publication. EFSA Panel on Biological Hazards (BIOHAZ) Panel; Scientific Opinion on the risk posed by pathogens in food of non-animal origin. Part 1 (outbreak data analysis and risk ranking of food/pathogen combinations). Parma, Italy: European Food Safety Authority. The EFSA Journal, 2012 No. 3025, Vol.. 10(1), DOI: 10.2903/ j.efsa.2013.3025

14. Hakim FA. Blue Economy daerah Pesisir Berbasis Kelautan dan Perikanan. EDAJ. 2013; 2(2): 1-7

15. Hidayat. Peningkatan kapasitas kelembagaan nelayan. Jurnal Sejarah CITRA LEKHA. 2013; $17(1): 43-58$

16. Rudianto DF. Dampak Pelaksanaan Program Gerakan Memasyarakatkan Makan Ikan (Gemarikan) Terhadap Peningkatan Konsumsi Ikan Rumah Tangga Kecamatan Lowokwaru Kota Malang. Sarjana thesis, Universitas Brawijaya. 2017

17. Shimamura Y, Muwanwella N, Chandran S, Kandel G, Marcon N. Common Symptoms from an Uncommon Infection: Gastrointestinal Anisakiasis. Can J Gastroenterol Hepatol. 2016, Article ID 5176502, 7 pages http://dx.doi.org/ $\underline{10.1155 / 2016 / 5176502}$

18. Anshary H, Sriwulan, Mark A. Freeman MA, Ogawa K. Occurrence and Molecular Identification of Anisakis Dujardin, 1845 from Marine Fish in Southern Makassar Strait, Indonesia. Korean J Parasitol. 2014; 52(1): 9-19

19. Topuz OK, Gökoðlu N. Anisakiasis: parasitic hazard in raw or uncooked seafood products and prevention ways. J food health Science. 2017; $3(1): 21-8$

20.Piccolo G, Manfredi MT, Hoste L, Vercruysse J. Anisakidae larval infection in fish fillets sold in Belgium. Veterinary Quarterly. 1999; 21(2): 667, DOI:10.1080/01652176.1999.9694995 